\title{
Penggunaan Model Inkuiri Terbimbing Berbantuan Media Audio Visual dalam Meningkatkan Kualitas Pembelajaran IPA pada Peserta Didik Kelas V SDN 111/IX Desa Muhajirin
}

\author{
Halimah $^{1}$ \\ ${ }^{1}$ Guru SD Negeri 111/IX Desa Muhajirin Kabupaten Muaro Jambi, Indonesia \\ Correspondance email: mahalimah.70@gmail.com
}

\begin{abstract}
Abstrak: Penelitian ini bermula dari rendahnya kualitas pembelajaran IPA peserta didik kelas V SDN 111/IX Desa Muhajirin. Hal tersebut ditunjukkan dengan ditemukannya beberapa masalah diantaranya guru belum optimal dalam membimbing peserta didik untuk mencari dan menemukan konsep materi pembelajaran secara mandiri., sehingga peserta didik belum termotivasi dan terfasilitasi untuk secara mandiri mempelajari materi pelajaran dengan pemenuannya sendiri, guru kurang membimbing peserta didik dalam memberikan masalah sehingga peserta didik belum terbiasa berfikir secara kritis dan analitis, hal tersebut di dukung data hasil belajar peserta didik rendah dengan ketuntasan klasikal mencapai $45 \%$. Jenis penelitian ini merupakan penelitian tindakan kelas yang dilaksanakan dalam tiga siklus. Setiap siklus dilaksanakan dalam satu pertemuan yang terdiri dari perencanaan, pelaksanaan, observasi dan refleksi. Subjek penelitian ini adalah guru dan peserta didik kelas V SDN 111/IX Desa Muhajirin dengan jumlah peserta didik sebanyak 36 peserta didik. Hasil penelitian menunjukkan keterampilan guru siklus I memperoleh skor 25 dengan kriteria cukup, siklus II memperoleh skor 34 dengan kriteria sangat baik dan siklus III memperoleh skor 36 dengan kriteria sangat baik. Aktivitas peserta didik pada siklus I memperoleh rata-rata jumlah skor 18,9 dengan kriteria cukup, siklus II memperoleh rata-rata jumlah skor 26,4 dengan kriteria baik dan siklus III memperoleh rata-rata jumlah skor 30,5 dengan kriteria baik. Hasil belajar peserta didik siklus I memperoleh rata-rata skor 62,56, siklus II memperoleh rata-rata skor 71,61 dan siklus III memperoleh rata-rata skor 78,22. Persentase ketuntasan klasikal hasil belajar peserta didik siklus I persentase $56 \%$, siklus II persentase $78 \%$ dan siklus III persentase $83 \%$..Sehingga dapat di simpulkan model inkuiri terbimbing berbantuan media audio visual dapat meningkatkan kualitas pembelajaran IPA pada peserta didik kelas V SDN 111/IX Desa Muhajirin.
\end{abstract}

Kata Kunci: Audio Visual, Inkuiri Terbimbing, IPA, Kualitas Pembelajaran

Abstract. This research based from the low quality of science learning in fifth grade students of SDN 111 / IX Muhajirin Village. This is indicated by the discovery of several problems including the teacher is not optimal in guiding students to search and find the concept of learning material independently, so that students have not been motivated and facilitated to independently learn the subject matter with their own pemenuan, teachers are less guiding students in providing problem so that students are not accustomed to thinking critically and analytically, it is supported by low student learning outcomes data with classical completeness reaching 45\%. This type of research is a classroom action research conducted in three cycles. Each cycle is carried out in one meeting consisting of planning, implementation, observation and reflection. The subjects of this study were teachers and students of class V SDN 111 / IX Muhajirin Village with a total of 36 students. The results showed the skills of the first cycle teachers received a score of 25 with sufficient criteria, the second cycle obtained a score of 34 with very good criteria and cycle III obtained a score of 36 with very good criteria. Activities of students in the first cycle obtained an average total score of 18.9 with sufficient criteria, second cycle obtained an average total score of 26.4 with good criteria and cycle III obtained an average total score of 30.5 with good criteria. Learning outcomes of students in cycle I obtained an average score of 62.56, cycle II obtained an average score of 71.61 and cycle III obtained an average score of 78.22. The percentage of classical completeness learning outcomes of students in cycle I percentage 56\%, cycle II percentage $78 \%$ and cycle III percentage $83 \%$. So that it can be concluded that guided inquiry model assisted by audio-visual media can improve the quality of science learning in class $V$ students of SDN 111 / IX Muhajirin Village.

Keywords: Audio Visual, Guided Inquiry, Science, Quality of Learning

\section{Pendahuluan}

Pada jenjang pendidikan dasar dan menengah mata pelajaran IPA harus mencakup beberapa standar kompetensi dan kompetensi dasar. Standar Kompetensi (SK) dan Kompetensi Dasar (KD) IPA di SD/MI merupakan standar minimum yang secara nasional harus dicapai oleh peserta didik dan menjadi acuan dalam pengembangan 
kurikulum di setiap satuan pendidikan. Pencapaian SK dan KD didasarkan pada pemberdayaan peserta didik untuk membangun kemampuan, bekerja ilmiah, dan pengetahuan sendiri yang difasilitasi oleh guru.

Permasalahan kualitas pembelajaran IPA yang belum optimal tersebut merupakan permasalahan yang sangat penting dan mendesak, sehingga perlu untuk dicari pemecahan masalahnya dalam memperbaiki kualitas pembelajaran IPA di kelas V. Untuk memecahkan permasalahan tersebut, peneliti berinisiatif menetapkan alternatif tindakan dengan menerapkan model pembelajaran inovatif yang dapat meningkatkan kualitas pembelajaran. Pembelajaran inovatif mengutamakan peran guru sebagai fasilitator, motivator, dan evaluator disamping informator. Sehingga, guru harus bisa menstimulus perhatian selektif peserta didik terhadap proses pembelajaran yang berlangsung.

Salah satu model pembelajaran inovatif yang dapat memecahkan masalah tersebut adalah dengan menerapkan model inkuiri terbimbing berbantuan media audio visual. Menurut Herdian (dalam Putra, 2013:96) model inkuiri terbimbing adalah model inkuiri yang dilaksanakan dalam pembelajaran, dimana guru membimbing peserta didik melakukan kegiatan dengan memberi pertanyaan awal dan mengarahkan kepada suatu diskusi. Pada model inkuiri terbimbing, guru banyak memberikan bimbingan pada tahap awal, namun pada tahap selanjutnya bimbinganbimbingan tersebut dikurangi. Penerapan model inkuiri terbimbing, peserta didik dapat menemukan jawaban secara mandiri dari berbagai permasalahan yang diutarakan serta memberikan pemahaman kepada peserta didik dalam mengenal, memahami berbagai materi menggunakan pendekatan ilmiah, bahwa informasi bisa berasal dari mana saja, kapan saja, tidak bergantung pada informasi searah dari guru. Oleh karena itu, kondisi pembelajaran yang tercipta diarahkan untuk mendorong peserta ddik dalam mencari tahu dari berbagai sumber observasi, bukan diberi tahu.

Penerapan model inkuiri dalam pembelajaran memberikan keleluasaan dan kebebasan peserta didik untuk mengeksplorasi seluruh kemampuannya tanpa harus terbebani. Model pembelajaran inkuiri pada prinsipnya tidak hanya mengajarkan peserta didik untuk memahami dan mendalami materi pembelajaran, tetapi juga melatih kemampuan berpikir peserta didik dengan baik. Model ini juga sangat memperhatikan gaya belajar tiap-tiap peserta didik saat mampu melayani peserta didik yang mempunyai kemampuan di atas rata-rata (Haryono, 2013).

Model inkuiri terbimbing akan lebih efektif dalam pelaksanaannya jika dite-rapkan dengan media pembelajaran. Indriana (2011) menyatakan bahwa media pembelajaran adalah salah satu alat komunikasi dalam pembelajaran. Penerapan media pembelajaran akan menjadikan pembelajaran lebih menarik bagi peserta didik, sehingga motivasi belajar peserta didik akan tumbuh. Selain itu media pembelajaran dapat mengaktifkan peserta didik, seperti mengamati, melakukan serta mendemostrasikan. Media pembelajaran yang digunakan dalam penelitian ini adalah media audio visual. Media audio visual menurut Djamarah dan Zain (2013) adalah media pembelajaran yang mempunyai unsur suara dan unsur gambar. Media audio visual dalam pembelajaran inkuiri terbimbing lebih menarik perhatian peserta didik karena terdapat beraneka gambar yang diselingi dengan suara sehingga mudah menstimulus otak peserta didik dalam mengingat pesan yang terdapat pada media audio visual tersebut. Media audio visual juga dapat mengatasi keterbatasan pengalaman yang dimiliki peseta didik, sehingga memungkinkan peserta didik untuk belajar dengan baik.

Pembelajaran dengan menerapkan model inkuiri terbimbing berbantuan media audio visual, peserta didik menjadi lebih aktif yang berakibat pada hasil belajar peserta didik juga akan meningkat. Selain itu, dengan penerapan alternatif pemecahan masalah tersebut peserta didik dapat menemukan sendiri konsep IPA yang dipelajari, dan membe-rikan ruang kepada peserta didik untuk belajar sesuai dengan gaya mereka, pengembangan aspek kognitif, afektif, dan psikomotor akan ditekankan secara seimbang, kebutuhan peserta didik yang memiliki kemampuan di atas rata-rata juga akan terlayani, sehingga pembelajaran dengan model inkuiri terbimbing berbantuan media audio visual dianggap lebih bermakna.

Berdasarkan latar belakang masalah diatas, maka peneliti akan mengkaji masalah tersebut melalui penelitian tindakan kelas dengan judul "Peningkatan Kualitas Pembelajaran IPA melalui Model Inkuiri Terbimbing Berbantuan Media Audio Visual pada Peserta Didik Kelas V SDN 111/IX Desa Muhajirin”.

\section{LANDASAN TEORI}

berikut.

Beberapa aspek yang digunakan peneliti untuk mengkaji permasalahan dalam penelitian ini diuraikan sebagai

\section{Pemilihan Media Pembelajaran}

Guru perlu memperhatikan beberapa kriteria media yang efektif untuk digunakan dalam mendukung pembelajarannya. Menurut Sudjana dan Rivai (2013:4-5) dalam memilih media untuk proses pembelajaran, kriteriakriteria yang harus diperhatikan yaitu:

1. Ketepatannya dengan tujuan pembelajaran

Media pembelajaran dipilih berdasarkan tujuan-tujuan instruksional yang telah ditetapkan. Tujuan instruksional tersebut memuat unsur pemahaman, aplikasi, analisis, sintesis lebih memungkinkan digunakannya media pembelajaran.

2. Dukungan terhadap isi bahan pelajaran

Materi pembelajaran yang bersifat fakta, prinsip, konsep, dan generalisasi sangat memerlukan media agar peserta didik mudah dalam mempelajari materi pembelajaran tersebut. 
3. Kemudahan memperoleh media

Media yang akan digunakan mudah dalam mendapatkanya, setidaknya mudah dibuat oleh guru pada waktu mengajar.

4. Keterampilan guru dalam menggunakannya

Keterampilan guru dalam menggunakan media pembelajaran akan berdampak dalam mempertinggi kualitas pembelajaran.

\section{Hasil Belajar}

Hasil belajar berkaitan dengan perubahan perilaku yang diperoleh peserta didik setelah mengalami kegiatan belajar. Perolehan aspek-aspek perubahan perilaku tersebut bergantung pada apa yang telah dipelajari oleh peserta didik. Suprijono (2012) menyatakan bahwa hasil belajar adalah pola-pola perbuatan, nilai-nilai, pengertian-pengertian, sikap-sikap, apresiasi dan keterampilan. Berdasarkan pemikiran Gagne, hasil belajar berupa: (1) informasi verbal; (2) keterampilan intelektual; (3) strategi kognitif; (4) keterampilan motorik; (5) sikap.

Berdasarkan penjelasan tentang hasil belajar, dapat disimpulkan bahwa peserta didik dapat dikatakan berhasil dalam pembelajaran, apabila pengetahuan, keterampilan, sikap atau perilaku, pengalaman, dan daya pikir peserta didik mengalami peningkatan dan perubahan ke arah yang lebih baik. Pengetahuan, sikap serta perilaku dalam sebuah hasil belajar bersifat komprehensif, tidak secara terpisah-pisah. Hasil belajar peserta didik digunakan guru untuk dijadikan ukuran atau kriteria dalam mencapai suatu tujuan pembelajaran. Adapun indikator pencapaian hasil belajar peserta didik untuk ranah kognitif dalam pembelajaran IPA pada materi daur air dengan menerapkan model inkuiri terbimbing berbantuan media audio visual diantaranya: (1) menjelaskan pengertian daur air; (2) mengidentifikasi percobaan proses daur air; membuat laporan percobaan proses daur air ; (4) menjelaskan manfaat air; (5) menjelaskan cara menghemat air; (6) menganalisis kegiatan manusia yang mem-pengaruhi daur air; (7) melakukan percobaan pemborosan air; (8) membuat laporan percobaan pemborosan air; (9) menganalisis permasalahan air; (10) menjelaskan solusi permasalahan air di lingkungan; (11) merancang percobaan penjernihan air; dan (12) membuat laporan percobaan daur air.

Indikator pencapaian hasil belajar siswa untuk ranah afektif adalah: (1) antusias dalam mengamati media audio visual; (2) menganalisis media audio vi-sual dengan mempertanggungjawabkan hasilnya; (3) tekun dalam pencarian in-formasi untuk merumuskan hipotesis; (4) dapat melaksanakan kerja sama dalam pembelajaran perseorangan maupun berkelompok; (5) mengemukakan pertanyaan dan jawaban dengan jujur; (6) memaparkan hasil diskusi dengan percaya diri; dan disiplin dalam mengerjakan tugas yang diberikan guru.

Indikator pencapaian hasil belajar peserta didik untuk ranah psikomotorik adalah:

1. Menanggapi apersepsi;

2. Melaksanakan kegiatan diskusi kelompok dengan aktif;

3. Melakukan penemuan konsep materi pelajaran dengan bimbingan;

4. Menyampaikan hasil hipotesisnya;

5. Melakukan refleksi pembelajaran.

\section{Pengertian Model Pembelajaran Inkuiri}

Inkuiri adalah proses pembelajaran berdasarkan pada pencarian dan penemuan melalui proses berpikir secara sistematis. Pengetahuan diartikan sebagai proses menemukan sendiri. Inkuiri merupakan bagian inti dari kegiatan pembelajaran berbasis kontekstual. Pengetahuan dan keterampilan yang diperoleh peserta didik diharapkan bukan hasil mengingat seperangkat fakta-fakta, tetapi hasil dari penemuan sendiri. Model pembelajaran inkuiri berarti suatu rangkaian kegiatan belajar yang meli-batkan secara maksimal seluruh kemampuan siswa untuk mencari dan menyelidiki secara sistematis, kritis, logis, analitis, sehingga mereka dapat merumuskan sendiri penemuannya dengan penuh percaya diri. Sasaran utama kegiatan pembelajaran inkuiri adalah: (1) keterlibatan peserta didik secara maksimal dalam proses kegiatan belajar; (2) keterarahan kegiatan secara logis dan sistematis pada tujuan pembelajaran; dan (3) mengembangkan sikap percaya pada diri peserta didik tentang apa yang ditemukan dalam proses inkuiri.

Dari beberapa uraian tersebut dapat ditarik kesimpulan bahwa yang dimaksud dengan inkuiri adalah kegiatan pembelajaran yang melibatkan peserta didik untuk dapat menemukan sendiri pengetahuan yang dipelajari melalui beberapa tahap menuju suatu kesimpulan yang meyakinkan karena didukung oleh data dan ke nyataan. Peserta didik secara maksimal melibatkan seluruh potensi yang dimilikinya untuk menemukan suatu konsep yang dipelajarinya. Sehingga dengan penemuannya tersebut, konsep yang ditemukan akan lebih bermakna dibandingkan dengan konsep yang secara instan hanya diterimanya dari orang lain.

\section{Karakteristik Inkuiri}

Hamdani (2011) menyatakan bahwa karakteristik inkuiri adalah membimbing, melatih, dan membiasakan peserta didik untuk dapat terampil dalam berpikir, karena secara mental dan fisik peserta didik terlibat langsung dalam 
pembelajaran. Pelatihan dan pembiasaan peserta didik untuk terampil berpikir merupakan hal yang penting untuk mencapai tujuan pembelajaran yang telah ditetapkan serta hasil belajar yang dikehendaki. Keterangan dari penjelasan tersebut adalah esensi dari model inkuiri terbimbing yaitu untuk melibatkan peserta didik dalam masalah penyelidikan asli dengan menghadapkan mereka pada investigasi luas, membantu mereka mengidentifikasi masalah konseptual atau metodologis dalam penyelidikan, dan mengajak mereka untuk merancang cara mengatasi masalah itu. Dengan demikian, mereka meliha dalam pembuatan pengetahuan dan diinisiasi ke dalam komunitas ilmuwan. Pada saat yang sama, mereka akan mendapatkan pengetahuan serta rasa hormat untuk belajar lebih baik dengan adanya ketergantungan dan keterbatasan pengetahuan saat ini.

Menurut Wisudawati dan Sulistyowati (2014) model pembelajaran inkuiri memiliki unsur penting yang harus diperhatikan dalam pelaksanaan pembelajaran IPA, yaitu:

1. Materi IPA yang dipelajari berhubungan dengan konteks masalah dan fenomena yang dijumpai oleh peserta didik;

2. Masalah yang akan dipelajari harus sesuai dengan kenyataan dan update;

3. Material yang akan digunakan tersedia;

4. Pola pertanyaan yang diajukan oleh guru untuk pengarah harus fokus;

5. Pola pertanyaan peserta didik untuk merumuskan masalah harus sesuai;

6. Perumusan masalah dan hipotesis yang diajukan peserta didik harus diperiksa oleh guru;

7. Data harus dikumpulkan dengan baik oleh peserta didik;

8. Mengoptimalkan nilai tanggung jawab dan rasa ingin tahu (curiosity) pada diri peserta didikketika mengumpulkan data;

9. Dalam pengambilan kesimpulan harus tetap berpedoman pada konsep IPA yang benar, jika diperlukan guru selalu membimbing;

10. Lembar kegiatan peserta didik harus dipersiapkan sebelumnya;

11. Lembar asesmen kognitif, afektif, dan psikomotorik harus dipersiapkan guru sebelum proses pembelajaran dan disesuaikan dengan model pembelajaran;

12. Guru menentukan tempat yang akan digunakan untuk pembelajaran IPA.

Dari uraian tersebut dapat disimpulkan bahwa tujuan utama model pembelajaran inkuiri adalah mengembangkan penguasaan pengetahuan, yang didapatkan dari hasil pengolahan informasi. Penguasaan pengetahuan yang dimiliki seorang peserta didik didapatkan dari hasil penemuannya yang berlangsung dalam pembelajaran. Penemuan yang didapatkan diperoleh melalui serangkaian kegiatan ilmiah yang telah direncanakan oleh guru, maupun guru beserta peserta didik.

\section{Langkah-langkah Pembelajaran Inkuiri Terbimbing}

1) Orientasi

Menurut Hosnan (2014), langkah-langkah model inkuiri terbimbing adalah sebagai berikut.

Pada tahap orientasi guru mengondisikan peserta didik untuk siap melaksanakan proses pembelajaran. Guru menentukan topik penyelidikan serta merangsang dan mengajak peserta didik untuk berpikir memecahkan masalah.

2) Merumuskan Masalah

Merumuskan masalah merupakan langkah untuk membawa peserta didik pada s-atu persoalan yang mengandung teka-teki. Persoalan yang diberikan adalah persoalan yang menantang siswa untuk berpikir memecahkan tekateki tersebut. Guru mengembangkan pertanyaan-pertanyaan terkait topik penyelidikan.

3) Merumuskan Hipotesis

Hipotesis adalah jawaban sementara dari suatu permasalahan yang diselidiki. Guru membimbing peserta didik untuk merumuskan hipotesis. Hipotesis yang akan dirumuskan peserta didik harus memiliki landasan berpikir yang kokoh, sehingga hipotesis yang dirumuskan bersifat rasional dan logis.

4) Mengumpulkan Data

Mengumpulkan data adalah aktivitas mencari informasi yang dibutuhkan untuk menguji hipotesis yang dirumuskan. Guru dalam tahap ini mendorong peserta didik untuk berpikir menemukan informasi yang dibutuhkan dengan mengajukan pertanyaan-pertanyaan

5) Menguji Hipotesis

Menguji hipotesis adalah proses menentukan jawaban yang dianggap diterima sesuai dengan data atau informasi yang diperoleh berdasarkan pengumpulan data. Pada tahap ini guru membimbing peserta didik untuk menganalisis data yang hasilnya akan disampaikan di depan kelas.

6) Merumuskan Kesimpulan 
Merumuskan kesimpulan adalah proses mendeskripsikan temuan yang diperoleh berdasarkan hasil pengujian hipotesis. Guru membimbing pesertadidik untuk merumuskan kesimpulan sesuai dengan data yang relevan.

Pada dasarnya penerapan inkuiri terbimbing menurut Herdian (dalam Putra, 2013:96), peserta didik akan memperoleh pedoman sesuai yang diperlukan selama proses pembelajaran. Pada tahap awal guru banyak memberikan bimbingan. Kemudian, pada tahap-tahap berikutnya, bimbingan tersebut dikurangi, sehingga peserta didik mampu melakukan proses inkuiri secara mandiri. Penerapan model inkuiri ini dapat dilakukan dalam proses pembelajaran kontekstual, dimulai atas kesadaran peserta didik akan memecahkan masalah yang jelas yang ingin dipecahkan. Pada penelitian ini menerapkan inkuiri terbimbing, yang langkah-langkahnya secara umum telah dipaparkan oleh para ahli tersebut. Pada inkuiri terbimbing guru masih berkecimpung untuk membimbing peserta didik dalam menemukan suatu konsep. Dalam hal ini, guru sedikit demi sedikit mengurangi bimbingannya selama pembelajaran berlangsung.

\section{Pengertian Media Audio Visual}

Menurut Hamdani (2011) media audio visual merupakan media yang mengandung unsur suara dan juga memiliki unsur gambar yang dapat dilihat, seperti rekaman video, film, dan sebagainya. Sedangkan menurut Anitah (2011), media audio visual merupakan kombinasi dari media audio dan media visual atau disebut media pandang dengar. Selain itu, pengertian yang lain disam-paikan oleh Sukiman (2012), menurut Sukiman media pembelajaran berbasis audiovisual adalah media yang digunakan untuk penyalur pesan dengan meman-faatkan indera pendengaran dan penglihatan. Media audio visual memiliki efek-tivitas lebih tinggi daripada media visual atau audio. Hal tersebut ditunjukkan dengan kerucut pengalaman Edgar Dale

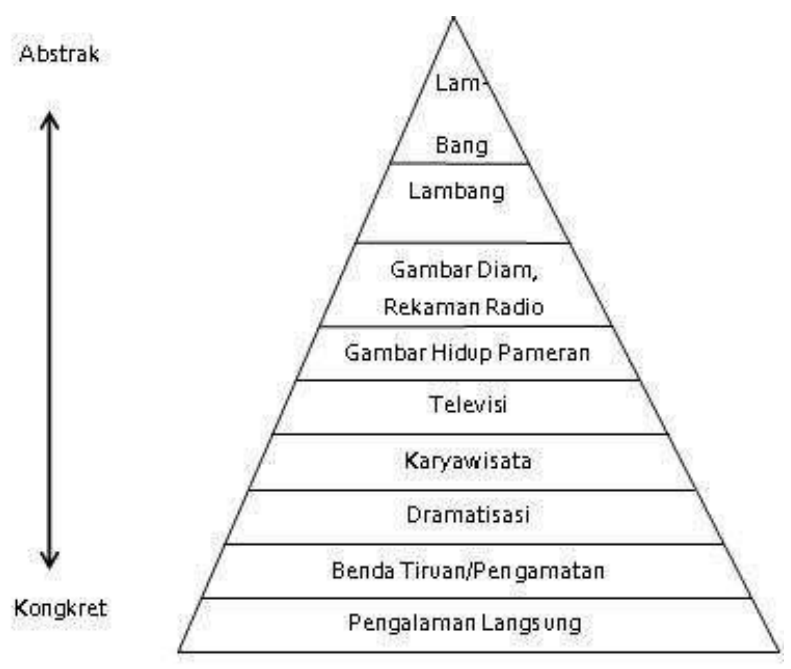

Gambar 1 Kerucut Pengalaman Edgar Dale

Kerucut tersebut merupakan elaborasi yang rinci dari konsep tiga tingkatan pengalaman. Semakin ke atas di puncak kerucut semakin abstrak media penyam-pai pesan. Dasar pengembangan kerucut tersebut berdasarkan tingkat keabstrakan jumlah indera yang turut serta dalam menerima isi pembelajaran. Pengalaman langsung berpengaruh pada kesan yang didapat siswa secara utuh dan paling ber-makna mengenai isi pembelajaran melalui semua indera yang dimilikinya.

Berdasarkan uraian tersebut, dapat disimpulkan bahwa media audio visual merupakan media pembelajaran berbasis audio dan visual yang digunakan sebagai sarana penyaluran pesan. Pesan yang disampaikan dengan media audio visual a-kan memberikan pengalaman langsung yang bermakna dan berkesan pada siswa. Pembelajaran dengan menggunakan media audio visual pada siswa SD, akan membantu siswa untuk belajar lebih banyak, daripada siswa yang hanya belajar dengan rangsangan pandang saja atau hanya belajar dengan rangsangan dengar saja karena siswa SD masih dalam usia operasional konkret, sehingga siswa menggunakan pancainderanya untuk memahami pesan yang disalurkan.

\section{Langkah-langkah Penggunaan Media Audio Visual}

Penggunaan media pembelajaran harus disesuaikan dengan materi pelajaran. Berikut ini langkah-langkah menurut Djamarah dan Zain (2013) dalam peng-gunaan audio visual adalah:

1) Merumuskan tujuan pembelajaran dengan memanfaatkan media audio visual sebagai media pembelajaran. Media audio visual ditulis dalam tujuan pembelajaran yang akan disampaikan oleh guru kepada peserta didik; 
2) Persiapan guru. Guru memilih dan menetapkan media yang akan dipakai guna mencapai tujuan. Media yang dipilih harus diperhatikan dan sesuai dengan materi atau konsep mata pelajaran yang akan disampaikan;

3) Persiapan kelas. Peserta didik melakukan persiapan sebelum mereka menerima pelajaran dengan menggunakan media audio visual. Persiapan tersebut meliputi kondisi fisik dan psikis peserta didik serta segala sesuatu yang akan di butuhkan oleh peserta didik misalnya alat-alat tulis;

4) Langkah penyajian pelajaran dan pemanfaatan media. Penyajian bahan pelajaran dengan memanfaatkan media pembelajaran akan berjalan lancar apabi la guru memiliki keahlian dalam menggunakan media pembelajaran sehingga tujuan pembelajaran dapat tercapai tanpa ada hambatan dari guru;

5) Langkah kegiatan belajar peserta didik. Pada fase ini peserta didik belajar dengan meman-faatkan media pengajaran yang ada. Sebagai contoh peserta didik mempraktikkan mengenai isi dari media sesuai dengan kegiatan pembelajaran atau peserta didik dilatih cara mengerjakan soal latihan dengan media yang ada dengan bimbingan guru;

6) langkah evaluasi pengajaran. Pada langkah ini siswa dievaluasi oleh guru mengenai sampai sejauh mana tujuan pengajaran yang dicapai, sekaligus dapat dinilai sejauh mana pengaruh media sebagai alat bantu dapat menunjang keberhasilan proses belajar peserta didik.

Jenis-jenis Media Audio Visual

Media audio visual ini memiliki banyak jenisnya, Anitah (2011) menyebutkan dua macam media audio visual yaitu slide suara dan televisi. Munadi (dalam Sufanti,2010) menyebutkan jenis media audio visual yaitu film bersuara, televisi dan video. Berdasarkan pendapat tersebut, Sufanti (2010) me-maparkan jenis-jenis media audio visual sebagai berikut.

1. Film Bersuara atau slide bersuara Merupakan salah satu jenis media visual yang menampilkan sejumlah slide, dipadukan dalam suatu cerita atau suatu jenis pengetahuan yang diproyeksikan dan disajikan dengan suara sebagai pengiringnya.

2. Televisi : Televisi berasal dari kata tele dan visi yang berarti jauh dan penglihatan. Dengan kata lain, televisi merupakan program yang memperlihatkan sesuatu dari jauh. Makna televisi dan film sebenarnya sama yaitu didengar dan dilihat karena peranannya sebagai gambar hidup dan juga sebagai radio.

3. Video: Video merupakan perangkat lunak berupa rekaman suatu peristiwa yang di-putar dengan media video. Dengan media ini memudahkan untuk perulangan. Kaset yang berisi rekaman bisa diputar berulang-ulang, dihentikan, dan diputar sesuai keinginan.

Berdasarkan klasifikasi media audio visual tersebut, pada pembelajaran IPA melalui model inkuiri terbimbing berbantuan media audio visual akan mengguna-kan media berupa slide bersuara. Penggunaan slide suara akan menarik perhatian peserta didik dengan adanya gambar-gambar yang menarik serta berwarna-warni dan terdapat efek suara yang dapat memudahkan peserta didik untuk membangun konsep materi secara mendiri.

\section{METODE PENELITIAN}

Jenis penelitian ini adalah penelitian tindakan kelas (PTK). PTK menurut Arikunto (2012) adalah suatu pencermatan terhadap kegiatan belajar berupa sebuah tindakan, yang sengaja dimunculkan dan terjadi dalam sebuah kelas secara bersama. Tindakan dalam PTK diberikan oleh guru atau dengan arahan dari guru yang dilakukan oleh siswa. Tahap penelitian dalam PTK, umumnya melalui empat tahap dalam satu siklus, yaitu: (1) perencanaan; (2) pelaksanaan; (3) pengamatan, dan (4) refleksi (Arikunto, 2012). Prosedur tersebut dilakukan secara berulang sampai perbaikan atau peningkatan yang diharapkan tercapai.

\section{HASIL DAN PEMBAHASAN}

Subjek penelitian dalam penelitian ini adalah guru dan peserta didik kelas V SDN 111/IX Desa Muhajirin. Peserta didik kelas V SDN 111/IX Desa Muhajirin sebanyak 36 peserta didik yang terdiri dari 21 peserta didik perempuan dan 15 peserta didik laki-laki. Penelitian ini dilaksanakan di SDN 111/IX Desa Muhajirin.

\section{Data Kuantitatif}

Data kuantitatif berupa hasil belajar kognitif, yang dianalisis dengan menggunakan teknik analisis deskriptif dengan menggunakan mean atau rerata, median, modus, dan ketuntasan belajar secara individual/klasikal yang ditampilkan dalam bentuk persentase.

Hasil penghitungan dikonsultasikan dengan kriteria ketuntasan minimal (KKM) SDN 111/IX Desa Muhajirin dengan KKM klasikal dan individual dikelompokkan ke dalam dua kategori tuntas dan tidak tuntas, dengan kriteria sebagai berikut 
Tabel 1. Kriteria Ketuntasan belajar

\begin{tabular}{ccc}
\hline Kriteria ketuntasan klasikal & Kriteria Ketuntasan individu & Kualifikasi \\
\hline$\geq 75 \%$ & $\geq 65$ & Tuntas \\
$<75 \%$ & $<65$ & Tidak Tuntas \\
\hline Sumber : SK KKM SDN 111/IX Desa Muhajirin & &
\end{tabular}

\section{Data Kualitatif}

Data kualitatif berupa data hasil observasi dalam pembelajaran IPA melalui model inkuiri terbimbing berbantuan media audio visual, serta hasil catatan lapangan dan wawancara dianalisis dengan analisis deskriptif kualitatif, dengan cara diorganisasikan, diklasifikasikan berdasarkan aspek-aspek yang menjadi fokus analisis menurut kategori untuk memperoleh kesimpulan. Untuk data hasil observasi keterampilan guru dan aktivitas peserta didik diklasifikasikan dalam empat kategori, yaitu sangat baik, baik, cukup, dan kurang sesuai dengan skor yang telah ditetapkan.

Berdasarkan uraian tersebut, kriteria data skor yang diperoleh dapat dikonversikan dalam bentuk tabel berikut:

Tabel 2. Kriteria Ketuntasan Keterampilan Mengajar Guru

\begin{tabular}{ccc}
\hline Jumlah Skor & Kualifikasi & $\begin{array}{c}\text { Tingkat Keberhasilan Aktivitas } \\
\text { Peserta Didik }\end{array}$ \\
\hline$>32,5 \mathrm{~s} / \mathrm{d} 40$ & Sangat baik (A) & Berhasil \\
$>25 \mathrm{~s} / \mathrm{d} 32,5$ & Baik (B) & Berhasil \\
$>17,5 \mathrm{~s} / \mathrm{d}<25$ & Cukup (C) & Tidak Berhasil \\
\hline
\end{tabular}

Tabel 3. Kriteria Ketuntasan Aktivitas Peserta Didik

\begin{tabular}{ccc}
\hline Jumlah Skor & Kualifikasi & $\begin{array}{c}\text { Tingkat Keberhasilan } \\
\text { Aktivitas Siswa }\end{array}$ \\
\hline$>32,5 \mathrm{~s} / \mathrm{d} 40$ & Sangat baik (A) & Berhasil \\
$>25 \mathrm{~s} / \mathrm{d} 32,5$ & Baik (B) & Berhasil \\
$>17,5 \mathrm{~s} / \mathrm{d}<25$ & Cukup (C) & Tidak Berhasil \\
$10 \mathrm{~s} / \mathrm{d} 17,5$ & Kurang (D) & Tidak Berhasil \\
\hline
\end{tabular}

Proses pembelajaran IPA melalui model inkuiri terbimbing berbantuan me-dia audio visual dapat meningkatkan kualitas pembelajaran di kelas VA SDN Gisikdrono 03 Semarang dengan indikator sebagai berikut:

1) Keterampilan guru dalam pembelajaran IPA melalui model inkuiri terbimbing berbantuan media audio visual meningkat dengan kategori sekurang-kurangnya baik.

2) Aktivitas peserta didik dalam pembelajaran IPA melalui model inkuiri terbimbing berbantuan media audio visual meningkat dengan kategori sekurang-kurangnya baik.

Sebanyak $\geq 75 \%$ dari seluruh peserta didik kelas V SDN 111/IX Desa Muhajirin mengalami ketuntasan belajar individual sebesar $\geq 65$ dalam pembelajaran IPA melalui model inkuiri terbimbing berbantuan media audio visual.

\section{Kesimpulan}

Berdasarkan hasil penelitian pembelajaran IPA melalui model inkuiri terbimbing berbantuan media audio visual di kelas V SDN 111/IX Desa Muhajirin, peneliti menyimpulkan beberapa hal sebagai berikut:

1. Melalui model inkuiri terbibimbing berbantuan media audio visual pada pembelajaran IPA di kelas V SDN 111/IX Desa Muhajirin dapat meningkatkan keterampilan guru. Berdasarkan hasil observasi pada siklus I mendapatkan kriteria cukup, pada siklus II mendapatkan kriteria sangat baik, dan pada siklus III mendapatkan kriteria sangat baik. Peningkatan keterampilan guru pada ketiga siklusnya dapat ditunjukkan dengan adanya guru telah memfasilitasi peserta didik dalam melakukan percobaan serta memberikan beberapa pertanyaan arahan untuk merumuskan hipotesis, membimbing peserta didik dalam melakukan penyelidikan, dan merefleksi hasil pembelajaran. 
2. Melalui model inkuiri terbimbing berbantuan media audio visual pada pembelajaran IPA di kelas V SDN 111/IX Desa Muhajirin dapat meningkatkan aktivitas peserta didik. Berdasarkan hasil observasi aktivitas peserta didik pada pelaksanaan tindakan pada siklus I mendapatkan kriteria cukup, pada siklus II mendapatkan kriteria baik, dan pada siklus III mendapatkan kriteria baik. Peningkatan tersebut ditunjukkan dengan adanya keantusiasan peserta didik dalam bekerjasama dengan kelompok untuk melakukan percobaan serta berlatih menemukan pengetahuannya sendiri dengan mengolah informasi dari bimbingan guru berupa tanya jawab, serta peserta didik juga mulai berani mengajukan pertanyaan mengenai materi yang belum dipahami kepada guru.

3. Melalui model inkuiri terbimbing berbantuan media audio visual pada pembelajaran IPA di kelas V SDN 111/IX Desa Muhajirin dapat meningkatkan hasil belajar peserta didik. Hal tersebut ditunjukkan dengan peningkatan hasil belajar peserta didik pada ketiga siklusnya. Pada siklus I mendapatkan ketuntasan klasikal $56 \%$ dengan rata-rata nilai sebesar 62,56, pada siklus II perolehan rata-rata 71,61 dengan ketuntasan klasikal hasil belajar 78\%, siklus III perolehan nilai rata-rata meningkat menjadi 78,22 dengan ketuntasan klasikal belajar pada siklus III ini yaitu $83 \%$.

\section{DAFTAR PUSTAKA}

Anitah W, Sri dkk. 2011. Strategi Pembelajaran di SD. Jakarta: Universitas Terbuka.

Arikunto, S, dkk. 2012. Penelitian Tindakan Kelas. Jakarta: Bumi Aksara.

Aqib, Zainal. 2013. Model-model, Media, dan Strategi Pembelajaran Kontekstual (Inovatif). Bandung: Yrama Widya.

Hosnan, M. 2014. Pendekatan Saintifik dan Kontekstual dalam Pembelajaran Abad 21. Bogor: Penerbit Ghalia Indonesia

Putra, Sitiatava Rizema. 2013. Desain Belajar Mengajar Kreatif Berbasis Sains. Yogyakarta: Diva Press.

Sudjana, Nana dan Ahmad Rivai. 2011.Media Pengajaran. Bandung: Sinar Baru Algensindo.

Sugiyono. 2014. Metode Penelitian Pendidikan (Pendekatan Kuantitatif, Kualitatif dan R\&D). Bandung: Alfabeta.

Sukiman. 2012. Pengembangan Media Pembelajaran. Yogyakarta : Padagogia.

Suprijono, Agus. 2012. Cooperative Learning. Yogyakarta : Pustaka Pelajar. 